\title{
2 \\ From Coombes to Coombs: Reflections on the Pitjantjatjara outstation movement
}

\author{
Bill Edwards
}

In September 1957, nearing the end of my studies at the University of Melbourne, I met the Reverend Victor Coombes, general secretary of the Presbyterian Board of Missions, to discuss the possibility of serving on a north Queensland Gulf mission. What motivated my interest in Aboriginal missions in an era when the more exotic overseas missions such as in the New Hebrides (Vanuatu) and Korea received more attention? Growing up in a very small country town in the Wimmera region of Victoria in the 1930s, I had little knowledge of Aboriginal people and their history. Monuments on nearby roads bearing the words 'Major Mitchell passed by here' suggested that this was the beginning of history. A rare meeting with an Aboriginal person was when a 'swagman' passed through my hometown of Lubeck. In return for the food my parents gave him, he cut firewood and gave my father an incised boomerang - now one of my prized possessions.

My studies in arts, education and theology in Melbourne contributed nothing to my knowledge of Aboriginal culture and history. However, in 1954, I visited universities around Australia as a staff worker with a Christian student organisation, the Inter-Varsity Fellowship. A visit to Adelaide in March that year coincided with a visit by the Ernabella Mission Choir. They came to see 
Queen Elizabeth II on her Australian tour. I heard them sing in the Teachers College and spent time with them at their accommodation, not imagining that four years later I would assume the role of conducting the choir. The next year, I visited Alice Springs as a member of a work party, and in 1957, I heard Doug Nicholls (later Sir Douglas) speak at the University of Melbourne, after his visit to the Western Desert region of Western Australia to investigate the effects of the Woomera rocket range tests on Aboriginal people. These events contributed to my interest in Aboriginal missions.

When I met Victor Coombes, he had recently visited Ernabella. Two matters arising from that visit led him to invite me to take on a role there as assistant to the superintendent, the Reverend Bruce Edenborough. First, my immediate responsibilities would be to assist him in this multifunctional role. Coombes obviously took note of the fact that I was raised in a country storekeeper's family and had worked as a bank clerk before entering university. These skills were required at Ernabella. Second, Coombes, concerned at the pressure on water and firewood supplies as the Ernabella population increased, proposed that a series of outstations be established to the west to enable some residents to return to their traditional homelands. He suggested that after a period at Ernabella, I would move to open the first of these outstations. After completing a Summer Institute of Linguistics course, I arrived at Ernabella on 2 May 1958. Ernabella is in the Musgrave Ranges in traditional lands of the Yankunytjatjara people, although the majority of residents are Pitjantjatjara. People of these Western Desert dialect groups are often referred to now as Anangu, a term meaning 'person' or 'body'.

Because of health problems, the Edenborough family left Ernabella in September 1958. I was appointed acting superintendent (and later superintendent). Thus, the plan to proceed to an outstation did not eventuate, although in 1961, I supervised the establishment of the first outstation, Fregon, and in later years spent much time visiting the newly established homeland communities of the 1970s. Here I will outline and reflect on the history of the Anangu outstation movement in the light of my own experiences and observations.

Several writers attribute the outstation movement to the influence of Dr H. C. ('Nugget') Coombs, an economist and former governor of the Reserve Bank, who in his retirement became involved in Aboriginal affairs. For example, another economist, Helen Hughes (2007: 11), referred to the 'Coombs socialist "homeland" model'. In this chapter, I will question Hughes' assumptions about this movement and its origins. I will refer to outstation movements in Aboriginal Australia that predated Coombs' involvement. As the term 'outstations' assumes the existence of previous 'stations', reference will be made to the establishment of mission and government settlements in the region and to the motivation for, and development of, the homeland movement in the Anangu region, and will 
conclude with brief comments on the present state of this movement. I will also question some of the romanticism expressed in some of the earlier writings about homelands.

The terms 'outstation' and 'homeland' are used interchangeably here. Outstation, a term with a long history of usage in Australia, was used in the Anangu area in the early stages of the movement. The term homeland was applied in Arnhem Land, and despite reservations about its use because of its connotations in South Africa during the apartheid era, its usage spread to other regions.

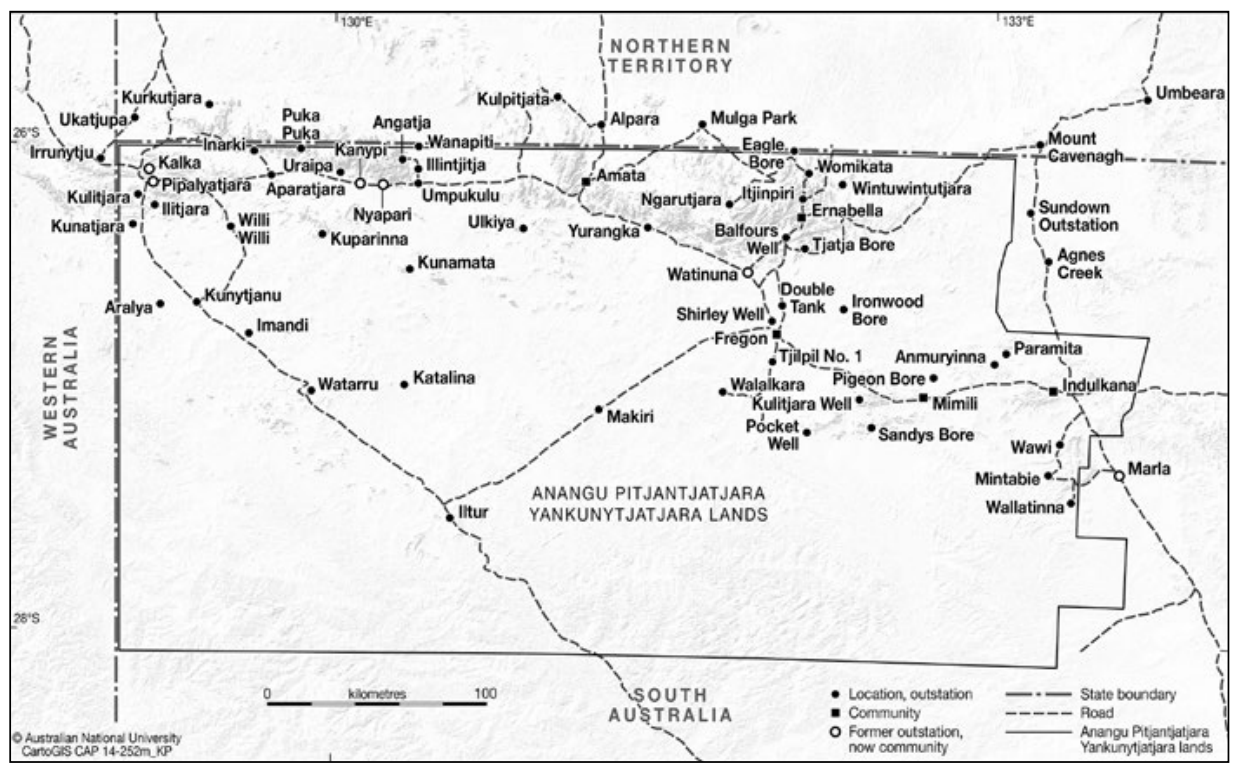

Map 2.1 Ernabella and its Pitjantjatjara outstations.

Source: Karina Pelling, CartoGIS, ANU College of Asia and the Pacific

\section{Literature review}

Before embarking on the history of settlements in the Anangu region, some issues raised in the literature associated with the homeland movement will be identified. In 1973, Dr Coombs presented a paper entitled 'Decentralization trends among Aboriginal communities' at the 45th Australian and New Zealand Association for the Advancement of Science (ANZAAS) Congress in Perth. As chairman of the Council of Aboriginal Affairs, he visited communities throughout Australia. He described the movement as 'one response to the complex problems created by contact with our society' (Coombs 1974: 135). 
He referred to the problems of institutionalism on settlements and tensions arising when people from different clans and language groups lived together on these stations. According to Coombs:

[A] growing desire to break away from this was stimulated by land rights campaigning and a desire to demonstrate the reality of these rights, reports of damage to sacred sites, increased access to income such as pensions and child endowment and changes of policy by government officials and missionaries who encouraged groups to assert their own identity. (1974: 136)

An arts administrator, Peter Brokensha, in The Pitjantjatjara and Their Crafts (1975), referred to problems associated with some early outstations as rivalry was engendered between groups as they competed for European resources. However, he concluded that the principal motivation for the return to sites was 'what could be termed an act of religious faith' (Brokensha 1975: 15). In an article published in 1977, Brokensha and McGuigan recorded that 200 people had left Amata, Ernabella and Fregon to establish homeland centres. While happy to be back in their lands, some women expressed concerns at the lack of health and education services and there was ambivalence as to the extent to which building development should take place and non-Aboriginal assistants be employed (Brokensha and McGuigan 1977: 120). A report in The Canberra Times of 15 November 1977 referred to a submission to establish a homeland health service. It claimed that 1,000 people had moved from the major settlements to 16 outstations (Waterford 1977). From my observation of the outstations at that time, I suggest that this figure was greatly inflated.

Noel Wallace, who undertook research at Amata settlement from the late 1960s and visited several traditional sites with groups of Anangu, wrote a comprehensive report on Pitjantjatjara decentralisation in 1977. While acknowledging that there were several motivations, he emphasised the desire to be near one's country, where spirit ancestors travelled (Wallace 1977: 124).

A report by Heppell and Wigley, also published in 1977, noted differing ideas about the movement between old and young people and suggested that the Coombs' model of simple camps was too restrictive and would frustrate the ambitions of younger people (1977: 4).

In an article in the Adelaide Preview in 1979, John Tregenza referred to the homeland movement as 'a rejection of European solutions to Aboriginal problems' (1979: 3). Tregenza, a welfare officer at Amata, moved to one of the first major outstations, at Wingelinna, as community adviser in 1975. He asserted that in earlier decades, Anangu had been encouraged to leave their lands and migrate to missions and government settlements to the east, where a colonial status quo was maintained. However, he overlooked the extent of migration that had taken place as the people themselves moved east because of 
drought, the attraction of new resources at the encroaching white settlements, the fact that those settlements were homelands to some of their residents, and the encouragement that had been given to Anangu to maintain links with their traditional sites. His assertion that 'white superintendents and their staff made all the decisions on behalf of their subjects' (Tregenza 1979: 3) disregarded the domains of Anangu life in which they continued to make decisions and the consultation that took place between staff and Anangu people.

Tregenza recorded that by 1976, 76 per cent of the Amata population had decentralised and that in 1979 there were 1,500 people in Pitjantjatjara homelands compared with only 500 at European-founded settlements (1979: 3). These figures do not correspond with demographic survey numbers I recorded in the area and appear to have been inflated to support proposals for the establishment of a homelands health centre. Figures I recorded are presented later in this chapter.

A report on the outstation movement published in 1980 by the Institute of Aboriginal Studies contained three papers written by Coombs, Barrie Dexter and Les Hiatt. They interpreted the movement as 'an attempt to select and integrate elements of both Aboriginal and European traditions in a context free from white domination' (Coombs et al. 1980: 19). They observed that while outstations were more peaceful than settlements, an initial euphoria was followed in some places by a degree of frustration and disputes over land ownership, leadership and property.

The most strident critic of the homelands movement was the late Helen Hughes, a Senior Fellow of the Centre for Independent Studies and frequent contributor to The Australian newspaper. While she assembled statistics to support her claims about welfare dependency, low educational standards and violence on remote communities, she made broad, unsubstantiated statements and underestimated the role of Anangu in establishing outstations. Her argument was based on a broad distinction between two models of Indigenous development: 1) a liberal model that aims to integrate Indigenous peoples into the economic mainstream; and 2) a socialist model that promotes separatism (Hughes 2007: 11). This dichotomy blurs the intricate nature of the movement. With her focus on Coombs, Hughes overlooked earlier outstation developments.

\section{Earlier Aboriginal outstation movements}

Much of the rhetoric associated with the homeland movement assumed that this was a new phenomenon, without precedent. However, Fregon was established as a result of Reverend Coombes' vision of outstation settlements. Much earlier, 
missions had experimented with similar proposals as they realised that tensions were created when people from several clans lived together in permanent settlements. For example, after the establishment of Mapoon Mission on Cape York Peninsula in north Queensland in 1891, as the population grew to 400, families settled at two outstations, in 1905 and 1906. They were designed to 'develop self-reliance and local energy' (W. Edwards 2007: 272). At these outstations, referred to as 'homesteads', the Aboriginal residents cultivated corn, pumpkins, cassava and other crops.

The Presbyterian Church established Aurukun Mission south of Mapoon in 1898. The Reverend Bill MacKenzie, who served there as superintendent from 1923 to 1965, also encouraged the people to settle on outstations in order to become more self-supporting and independent. A couple, Uki and Archiwald, established an outstation south of Aurukun in 1933 to work with people who lived in that region (B. Edwards 2009: 39; MacKenzie 1981: 140). This was an example of an earlier outstation based largely on Aboriginal initiative. Another outstation was established, at Peret, $25 \mathrm{~km}$ south of Aurukun, in the 1960s. Cattle camps, including Titree, were another example of outstations based on Aurukun. Other early examples of outstations in north Queensland were those established near the Church of England's Trebanaman Mission, later renamed Mitchell River, which was founded in 1905. In a 1922 publication, Logan Jack listed Angeram, Koongalara and Daphne as outstations (1922: 680).

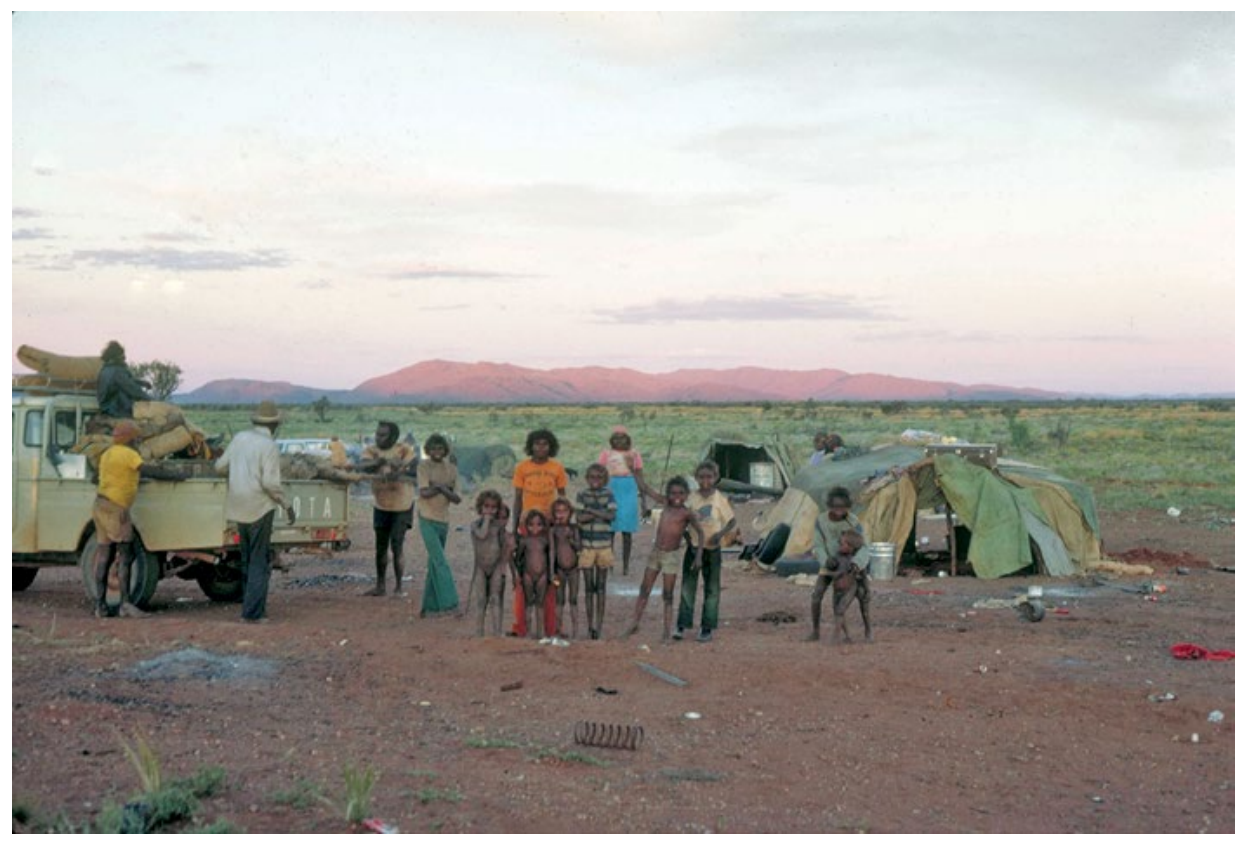

Figure 2.1 Aparatjara outstation in 1978.

Source: Bill Edwards 
One of the most adventurous efforts to support outstations was that of the Reverend Harold Shepherdson, who was appointed to the Methodist Mission at Milingimbi in Arnhem Land in 1927. In 1942, he established Elcho Island Mission. He and his wife, Ella, remained in Arnhem Land for 50 years. Shepherdson realised that the aeroplane was the answer to isolation and medical emergencies. In 1933 he sent to America for a blueprint for a monoplane, obtained linen from Ireland and an engine from England and constructed his own plane. Over the years he had several planes, which he used to supply outstations. Ella later wrote:

As many Aborigines wanted to stay in their own areas and not at the Mission Stations, the outstation work was conceived. These places were inaccessible except by aeroplane, so the people set to and cleared airstrips, using only hand tools, axes, shovels and saws. (Shepherdson 1981: 35)

In her memoir, Ella Shepherdson records the establishment of several outstations that her husband serviced by air, the first being at Gattji, $16 \mathrm{~km}$ south of Milingimbi (1981: 35-8). Nugget Coombs (1974: 140) referred to Shepherdson's 'courageous and imaginative servicing by air of these communities'.

In Central Australia, the Lutheran missionaries at Hermannsburg established outposts at Haasts Bluff (in 1941), Papunya (1954) and Areyonga (1942), to provide Aboriginal people with food and other resources in an attempt to limit the drift of people from the desert areas west of Hermannsburg towards Alice Springs and other railway settlements. Although missionaries supervised this development, Aboriginal people such as Manasse and Obed Raggett played important roles (Leske 1977: 54-61). These outposts later became government settlements. The above examples indicate that there were several outstations 'BC': Before Coombs.

\section{Mission and government settlements in the Anangu lands}

The Presbyterian Board of Missions established Ernabella Mission in 1937 at the instigation of an Adelaide surgeon, Dr Charles Duguid, who, having heard reports of the abuse of Aboriginal people, visited the region in June 1935. Returning to Adelaide, he advocated the establishment of a mission to act as a buffer between 'the white settlers east of it and the Native Reserve west of it' (Kerin 2011: 32). The 1,300 sq km Ernabella pastoral lease was purchased, and three other water permit blocks of the same size were added later. As the focus of this chapter is on homelands, there is no space for an extended outline of the history of the mission. This has been done in my recent monograph published by the Uniting Church Historical Society. Ernabella remained under 
the administration of the Presbyterian Board of Missions until the end of 1973. From 1 January 1974, control was transferred to the Ernabella Community Council Incorporated (B. Edwards 2012: 43-4).

During Ernabella's 36-plus years as a mission, sheep work was central to the economy and the employment of Anangu residents, as they worked as shepherds, shearers, fencing contractors, well sinkers and boring contractors. Women used a traditional method to spin wool for the making of hooked floor rugs, woven scarves and knee rugs in the craft industry that was established in 1948. A school based on a vernacular education policy was opened in 1940. From 1945, a nursing sister staffed a clinic. Anangu were employed as aides in the school and clinic.

After shearing, most of the people left on an annual spring 'walkabout' holiday, travelling west and south-west on camels, donkeys and on foot to visit traditional totemic areas. As this was the dingo pupping season, they caught pups and some adult dingoes, to exchange them for the government bounty. Staff members drove from Ernabella, taking flour, sugar, tinned food and other supplies to trade for the scalps at prearranged sites. These holidays lasted for approximately six weeks, with the school and craft room reopening when the people returned to Ernabella. A similar holiday was taken after Christmas. These breaks enabled Anangu to maintain contact with traditional sites and the related knowledge and ceremonies.

The SA Government's Aborigines Protection Board rejected Coombes' proposal that the Board of Missions be permitted to establish outstations of Ernabella on the North-West Aboriginal Reserve. Some members, including the secretary, were critical of Ernabella's policies of vernacular education and respect for traditional customs. In their eyes, Ernabella was not assimilating Aborigines quickly enough. The Protection Board decided to open its own settlement on the reserve at Amata.

Stymied by this rejection, the Board of Missions established an outstation of Ernabella on Shirley Well block, one of the three blocks granted as water leases. After discussion with people associated with this sandhill country, a site was selected on the banks of Officer Creek, a normally dry watercourse that ran from the Musgrave Ranges before petering out in the sandhill country further south. This site was approximately $50 \mathrm{~km}$ south-west of Ernabella. The new outstation, named Fregon after a benefactor, opened in October 1961 with a staff of four: an overseer, a cattle adviser, a teacher and a nursing sister, who also supervised craft work. Fregon was administered from Ernabella. One hundred cows with calves were purchased from a nearby station. Anangu, including Albert Lennon, Bernard Tjalkuriny, Michael Mitinkiri and Angkuna Tjitayi, 
played significant roles in Fregon's development. Planned to have a population of approximately 100, this increased to more than 200 in later decades. Fregon became a separate incorporated community in 1974.

In the meantime, the State Government went ahead with its plans for a government settlement on the reserve. This was opened in April 1961 towards the western end of the Musgrave Ranges, with six couples from Ernabella moving there. Two married couples originally staffed it. At first named Musgrave Park, the name was later changed to Amata, the name of a local waterhole. Musgrave Park was planned as a cattle station to provide employment. The cattle industry did not develop to the same extent as at Fregon as the Government found it difficult to recruit cattle overseers who could work cooperatively with Aboriginal people. A nursing sister was later stationed at Amata, and a school opened in 1967. The population grew as people moved from Ernabella and from other settlements and cattle stations.

Another government settlement was established, at Indulkana, approximately $145 \mathrm{~km}$ east of Fregon. Several Anangu families had resided on Granite Downs Station, where the men worked as stockmen. As the demand for labour declined with changes in handling cattle, some families moved to a waterhole in the Indulkana Creek. Following a change of ownership of the station, the SA Government negotiated the excision of an area of $30 \mathrm{sq} \mathrm{km}$ around the waterhole and gazetted it as an Aboriginal Reserve. Indulkana settlement opened in 1968 with a small staff and approximately 150 residents. A school opened in 1971. Thus, there were at that stage two mission and two government stations in the Anangu region. Indulkana was incorporated as Iwantja community in 1973 and Amata in 1974. Department for Community Welfare offices remained in these two communities with some control until the late 1970s. In 1973, the lease of Everard Park cattle station between Indulkana and Fregon was purchased by the Aboriginal Land Fund Commission and transferred to the local Aboriginal people, who renamed it Mimili. In 1976, a similar process saw the purchase of Kenmore Park Station east of Ernabella. It was renamed Inyarinyi. These, then, were the six stations established in the Anangu lands largely through the initiative of church and government authorities and on which the later establishment of outstations or homelands was predicated.

\section{The North-West Aboriginal Reserve in the 1960s}

While some writers on the homelands movement suggest that mission and government authorities had encouraged settlement on their stations and discouraged return to traditional areas, there are several examples of support for such movement. Reference has been made earlier to the assistance given 
by Ernabella Mission staff for Anangu to engage in the annual 'walkabout' holidays. During the late 1950s, a mining company undertook preliminary surveys of nickel deposits in the Mount Davies (SA) and Wingelinna (WA) areas. Bores were sunk to provide water for their camps. While these mining camps were occupied spasmodically, they provided bases for Anangu to obtain water and supplies.

The Amata Day Books contain frequent references to groups of people camping at Mount Davies during the 1960s. While they were largely dependent on bush foods, they were visited by staff from Amata, who provided rations in return for dingo scalps and artefacts. For example, on 12 May 1962, 27 people were taken from Amata to establish a camp in the Tomkinson Ranges. On 19 November, there were approximately 50 people in the Mount Davies camp. While drought conditions limited this development in 1964 and 1965, in the next few years there was considerable interest in mining chrysoprase, a jade-like rock associated with the nickel deposits, although this was done by men who travelled out each week from Amata, leaving their families at Amata.

A camp established in 1971 at Putaputa, $24 \mathrm{~km}$ east of Mount Davies, was a bridge between the 1960s camps serviced from Amata and the more independent outstations of the later 1970s. On 8 October 1971, I noted that there were two or three families, with water obtained from a bore equipped with a hand pump. Older men associated with important Malu (red kangaroo) Dreaming sites nearby, concerned that these sites might be disturbed by proposed nickel mining in the area, camped there to protect them. By 1976, a windmill and tank had been erected at Putaputa.

\section{The homeland movement of the 1970s}

Substantial changes were occurring in the policy, economic, employment and mobility situations relating to Anangu by the early 1970s. The 1967 referendum enabled the expenditure by the Commonwealth Government on Aboriginal programs in the States; Anangu had direct access to pensions and other social service benefits, the assimilation policy had been abandoned, steps were under way towards transferring administration of settlements to local incorporated councils and the number of privately owned motor vehicles had increased. These factors contributed to the development of the homeland movement from the mid-1970s. Another factor, as identified above in regard to Putaputa, was concern that culturally significant sites might be desecrated by prospecting and mining ventures in the region (Toyne and Vachon 1984: 35). The first two major homelands were situated near bores that had been put down to supply mining prospecting camps. 
I was able to observe the development of this movement, as, after two years' absence from the region, I returned to live at Amata from 1976 to 1980 as parish minister for the Pitjantjatjara Church - a parish stretching $600 \mathrm{~km}$ from east to west. In this role, I regularly visited the newly established outstations. During this period, I acted as interpreter and minute secretary for the newly formed Pitjantjatjara Council in negotiations leading to the granting of land rights. Although I moved to Adelaide in 1981 to lecture in Aboriginal studies, I visited the Anangu lands annually and continued to observe the movement.

The first outstation in this era was settled in 1974 at Wingelinna in Western Australia, near the border with South Australia and close to important papa (dingo) totemic sites. Following reports of the likely development of nickel mining, people moved from Amata to protect these sites. An Amata staff member was appointed community adviser, with a caravan provided as a residence. The WA Education Department appointed a teacher, with classes conducted in a brush shelter. As other families moved there from Amata and from Warburton Mission in Western Australia, the population reached approximately 170 by 1982 .

The second was established in 1975, at Pipalyatjara near the Mount Davies mining site in South Australia, $40 \mathrm{~km}$ from Wingelinna and $200 \mathrm{~km}$ west of Amata. It is near important Malu Dreaming sites. A government grant enabled the employment of a community adviser. A schoolteacher transferred from Amata to open a school in a brush shelter in 1976. A shed was erected to serve as a store. An airstrip previously used for the mining camp enabled light aircraft to land nearby. By 1982, the population had grown to 130 Anangu and 13 white residents, the latter including five children. Bulldozers were introduced to mine chrysoprase and this provided employment for some men. A garden was developed but had limited productivity. Bricks were made from local earth and a large building erected to house the store, office, school and clinic. Pipalyatjara took on the character of a settlement rather than an outstation and became a service centre for several outstation communities established in the area, as it provided stores and fuel and handled social service payments and communications. Some of these outstations were settled as residents of Pipalyatjara and Wingelinna moved away to avoid the same kind of tensions as had existed on the larger settlements as people from different local groups lived together for long periods.

In 1976, the Commonwealth Department of Aboriginal Affairs offered $\$ 10,000$ each for the establishment of four outstations: Cave Hill, Kunamata, Lake Wilson and Ilturnga (Coffin Hill). Ilturnga is $200 \mathrm{~km}$ south-west of Fregon across sandhill country. A road was graded from Fregon and a windmill and shed were erected. A few people from Fregon moved there, but because of remoteness, residence was spasmodic. In May 1976 a meeting was held at Amata to elect councils for the 
other three outstations. The budgets were intended to provide for the purchase of a windmill, tank, shed and second-hand Land Rover. These were seen as basic requirements. Cave Hill, $25 \mathrm{~km}$ north-east of Amata, is a Kungkarangkalpa (Seven Sisters) site. A few families from Ernabella and Amata settled there. Some returned to those larger settlements because of the lack of a school and the failure of a proposal to develop tourism. In the late 1970s, a father and son who had spent many years working on stations far to the south settled there because of matrilineal ties. They developed a garden and maintained housing at a reasonable standard. In 1987, the population was recorded as 20.

Some long-term Ernabella residents were related to important ili (native fig tree) sites at Kunamata, approximately $110 \mathrm{~km}$ south-west of Amata. They expressed resentment that priority had been given to the malu (kangaroo) group by the establishment of Pipalyatjara. Some, having obtained skills at Ernabella by working in the school, hospital and store, felt they could manage these services at Kunamata. However, while older people remained there, younger ones found it difficult to remain away from Ernabella. Water quality was a problem. Another incident that hindered progress was a fatal accident involving their motor vehicle on New Year's Day 1977, which led to tensions and reluctance to live there.

The grant allocated for Lake Wilson, a dry salt lake at the western end of the Mann Ranges, was used for a camp at Yaluyalu, south of Lake Wilson, as a bore was already there and it was on the Amata-Pipalyatjara road. People related to the Wayuta (possum) Dreaming moved there from Ernabella and Amata and, later, moved a few kilometres east to Aparatjara, approximately $150 \mathrm{~km}$ west of Amata. A few people were camped there in October 1976 and in December there were nine wiltja (bush shelters) and a store shed. Although they planned to conduct a store to supply others travelling on the road, the initial capital grant of $\$ 10,000$ was soon exhausted because of kinship obligations and lack of understanding about store financing. The site was intermittently occupied from 1978 to 1980, but again moved a short distance east. As older people died and there was friction between groups, there was occasional residence in the early 1980s, but the site was then deserted. A few people had moved to camp at Inarki, nearer Lake Wilson, in 1980 and a large area was cleared for a garden. This enterprise was short-lived. Although gardens were regarded as part of the model of an outstation and areas were fenced off and drip piping laid, little success was achieved (Cane and Stanley 1985: 126).

The establishment of the four outstations in 1976 motivated others to move to their traditional sites. In 1977, families associated with the wanampi (water serpent) story moved from Fregon and other settlements to camp at Kunytjanu, approximately $50 \mathrm{~km}$ south-east of Pipalyatjara. In May 1977, there were 13 brush shelters - two unoccupied - with 25 people living there, 
including five children. Most of the adults were elderly but one young man said that they would not ask the Government for help but would build the place themselves. They relied on social service payments and bush foods. By October, the population was reduced to three older couples. One couple remained there and in 1983 had a small single-room dwelling. However, the man later expressed sadness that younger people were not helping them and they also returned to Fregon.

Another outstation was established in 1979 at Walytjitjata, $38 \mathrm{~km}$ north-east of Pipalyatjara and just across the border in the Northern Territory. This was close to sites of kutungu (the first mother) and kampurarpa (bush tomato). The innovators in this outstation were two brothers who had lived at Indulkana. One worked for several years on stations further south, attaining skills that enabled them to build sheds, fences and a shower room. Trees were planted to provide shade. This man wanted to look after his father's country. There were approximately 20 people living there in October 1979. There were some tensions as other men resented his return after a long absence and accused him of bringing undesirable people to the area. After a fight, he moved to Alice Springs and the site was deserted until another group moved there by October 1983 and small houses were erected. However, it was again deserted in the late 1980s. Walytjitjata was similar to Cave Hill in that experience gained by men who had worked further south enabled them to construct and maintain infrastructure on the outstation. In 1982, 12 people were camped at Kurkutjara, $27 \mathrm{~km}$ north of Walytjitjata.

In March 1978, a group of older people moved to a remote nyiinyii (zebra finch) site approximately $40 \mathrm{~km}$ south of Wingelinna to establish Kata ala outstation. One reason for the move was the problem of alcohol abuse at Wingelinna. Thus already, as homeland communities were exhibiting some of the features of the older settlements, residents were motivated to leave them to create outstations. In November 1978, there were 15 men, 20 women and 18 children living in basic camp conditions at Kata ala, with water provided by a bore and tank.

In 1978, a Homelands Health Service was established at Kalka, $12 \mathrm{~km}$ north of Pipalyatjara. Large caravans accommodated a doctor, sister, administrator and clinic. The site was selected to indicate that it was to service homeland centres in the area and not just one community. However, several Anangu settled there and it became a community.

People camped at two sites near the road from Amata to Pipalyatjara on the southern side of the Mann Ranges in the late 1970s. An old man who was born in the Deering Hills further south camped at Kanpi, near a kalaya (emu) site in 1977. A few older women joined him in 1978. They were supplied with drums of water. Complaining of lack of support, they returned to Amata, but moved 
back to Kanpi in 1979 after the sinking of a bore. Residence was spasmodic until substantial houses and a store were erected by 1987. An innovation was the installation of a solar battery plant that supplied power for a freezer and house lighting. Another site, $10 \mathrm{~km}$ east of Kanpi, was occupied in 1979 by a group of people from Fregon but occupation was intermittent until 1987 when, as at Kanpi, houses were erected by the SA Aboriginal Housing Board. These two homelands have been regularly inhabited since then. In 1993, a school named Murputja was erected midway between Kanpi and Nyapari to service both homelands. An art centre, Tjungu Palya, was established at Nyapari to provide materials and retail services for residents of these two communities as well as Watarru homeland.

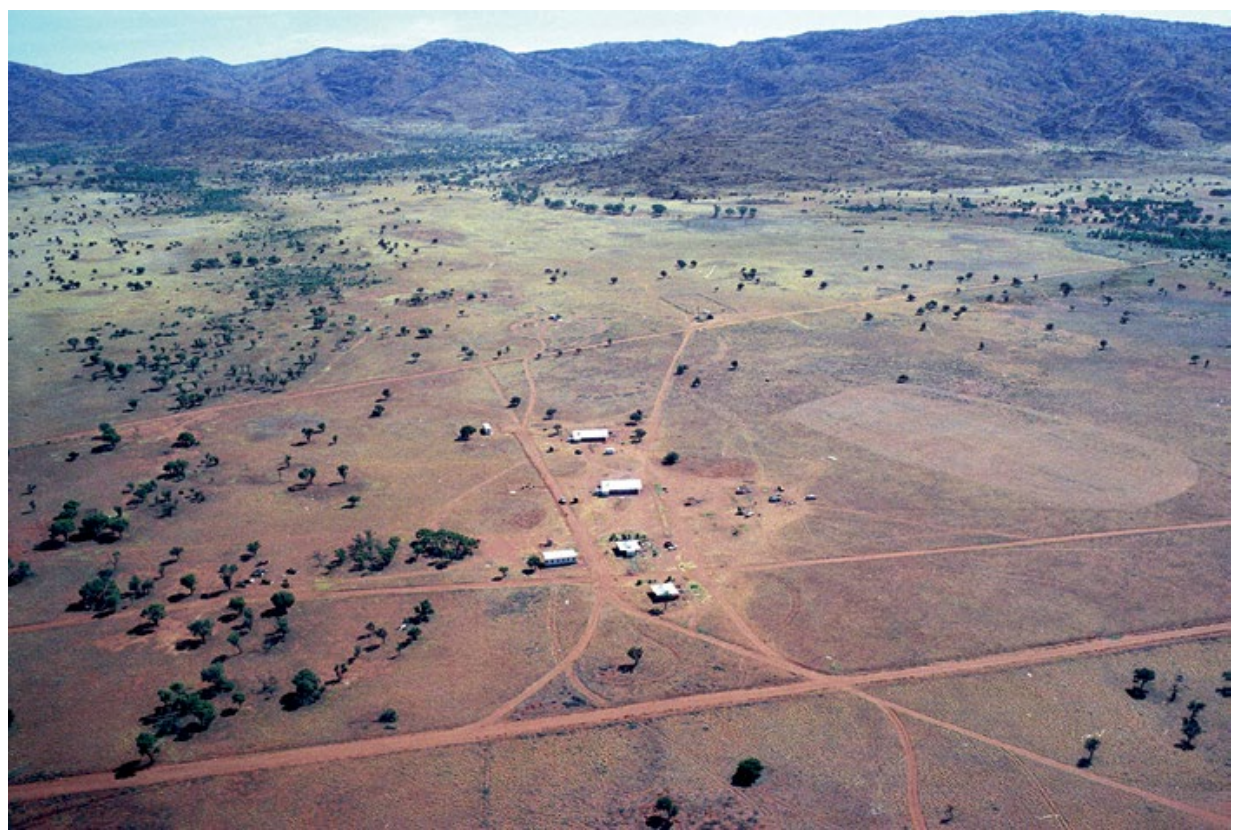

Figure 2.2 Nyapari outstation from the air, 1980s.

Source: Bill Edwards

Another significant centre was established, at Angatja, in a valley in the north-eastern section of the Mann Ranges, by Charlie Ilyatjari and his wife, Nganyintja, who had been prominent residents at Ernabella and Amata. This was Nganyintja's homeland, but her husband settled there, as he was concerned at the amount of alcohol consumption at his Wingelinna homeland. Angatja became the centre for two significant innovations. First, the couple developed it as a rehabilitation centre for children affected by petrol sniffing at Amata. Second, with the assistance of a white couple, they invited visitors to participate in a cross-cultural tourism experience. Another short-lived outstation in this 
area where some initiative was shown was Umpukula, $17 \mathrm{~km}$ east of Nyapari. As it was on the road, a couple who moved there from Amata had a baker's oven installed and made and sold bread to passers-by.

This brief history of the main homeland centres established to the west of the older settlements indicates that despite the rhetoric of a wholesale move of people from the Ernabella/Amata region, the occupancy of most of these centres was periodic. Several did not survive long but were deserted as older people died or returned to the settlements. Also, these centres were not immune from the tensions and social problems from which Anangu had sought refuge. The following population figures (Table 2.1) for the eastern and western communities in the 1980s refute claims that there was a mass movement of people to homelands. The 1981 and 1986 figures are based on Australian Bureau of Statistics census data. The 1982 figures are estimates provided by staff of settlements and my own count at the smaller homelands.

Table 2.1 Population figures

\begin{tabular}{|c|c|c|c|c|}
\hline & & 1981 & 1982 & 1986 \\
\hline \multirow[t]{7}{*}{ Eastern communities } & Amata & 180 & 200 & 277 \\
\hline & Ernabella & 322 & $300+$ & 365 \\
\hline & Fregon & 203 & $200+$ & 268 \\
\hline & Kenmore Park & 63 & 20 & 66 \\
\hline & Mimili & 132 & $100+$ & 145 \\
\hline & Indulkana & 301 & 250 & 238 \\
\hline & Mintabie & & & 49 \\
\hline \multirow[t]{8}{*}{ Western communities } & Kalka & 59 & 20 & 69 \\
\hline & Pipalyatjara & 64 & 120 & 102 \\
\hline & Wingelinna & & 170 & \\
\hline & Aparatjara & & 7 & \\
\hline & Angatja & & 10 & \\
\hline & Kunytjanu & & 4 & \\
\hline & Putaputa & & 11 & \\
\hline & Kurkaratjara & & 12 & \\
\hline
\end{tabular}

As the remote south-western outstation of Ilturnga was short-lived, residents of Fregon later opened a community at Watarru, near an isolated mountain, Mount Lindsay. As there was a fairly settled population there, a school was opened in 1986 and it remained one of the more stable homeland communities. However, as revealed in press reports, the population decreased due to tensions in the community and the school and store were closed in 2012 (Martin 2012: 40). 


\section{Satellite communities}

Another response to the political, economic and social changes of this period was the establishment of many outstations near the older settlements. Rather than move to distant western homelands, many people who had grown up or been born at Ernabella or nearby centres were attached to these places and desired to remain close to the employment, educational and health services afforded by them. I refer to these outstations, all of which fell within a $35 \mathrm{~km}$ radius of Ernabella, as 'satellite communities'. This initiative enabled people to escape from the tensions of the larger settlements and assert their own family identity and some degree of independence.

Several outstations were clustered around Ernabella, based on wells and bores used previously for watering sheep. Their residents belonged to four main categories. Katjikatjitjara, established in 1977, and Wintuwintutjara, both north-east of Ernabella, were established by men with patrilineal ties to sacred sites that they wished to protect. Second, Ngarutjara and Eagle Bore to the north-west of Ernabella were founded by men whose patrilineal ties were far to the west, but as they had lived most of their lives at Ernabella they wished to remain nearby. In the case of Ngarutjara, which is near Mount Woodroffe, the highest point in South Australia, a man whose totemic base was near Wingelinna claimed a right to Ngarutjara as his birthplace. He and his family later allowed visitors to climb Mount Woodroffe for a fee. Third, a man whose ties were with Kunamata, the ili (wild fig tree) site south-west of Amata, asserted his claim to Wamikata, a former sheep camp north of Ernabella, on the grounds that the ili had begun their Dreaming journey there. Fourth, some people who had been born to Anangu mothers and white fathers and raised in mission homes at Oodnadatta, Quorn and other centres returned to reclaim their heritage and lived at outstations including New Well and Turkey Bore.

This variety of claims and experiences reflected Fred Myers' conclusion concerning the Pintupi people that the limited resources in the Western Desert region necessitated greater flexibility and movement than in Arnhem Land, where the clan groups are more tightly structured and title to land is vested in named groups (Myers 1986: 138).

As funding for such centres increased in the early 1980s, more satellite communities were established with Ernabella as their service centre. In June 1988, informants identified 19 such satellite outstations, with eight reported as unoccupied at the time. 
This model of satellite communities was followed at Amata, Fregon, Mimili and Indulkana. In 1981, two families with traditional ties established an outstation at Katjikuta, $4 \mathrm{~km}$ east of Amata. Another man who had spent many years working on cattle stations claimed an area around Alpara, $30 \mathrm{~km}$ north of Amata, where he ran a cattle enterprise. Other outstations based on Amata were opened at Wintuwatu, Manyirkangka, Ulkiya, Yurangka and Tupul. Residence at most of these places was spasmodic. A man who had one grandparent with a link to the area and who lived in the Flinders Ranges area worked at Amata in the 1970s and his sons later joined him there. One married a local woman and they settled for a time at Tupul, $10 \mathrm{~km}$ north of Amata. They later returned to Amata.

As at Amata, cattle bores provided water for satellite outstations based on Fregon and Mimili. Those at Fregon included Shirley Well, Morrison Bore, Double Tank, Officer Creek, West Bore, Puupuu, Tjilpil and Ilitja. Attempts were made to develop small cattle projects at some of these sites. When Mimili was a cattle station, people had been encouraged to camp near cattle bores. When it became an Aboriginal-owned community, this tradition was maintained as people established outstations at Tita bore, Robb's Well, Pocket Well, Kulitjara and other sites. In the mid-1980s there were nine satellite outstations based on Indulkana, including Amaruna, Witjintitja, Ininti and Waawi.

Thus, at the same time as the homeland movement was developing in the western Anangu region, there was a significant movement to establish satellite outstations based on the older settlements in the eastern sector - a movement that was often given little attention as writers tended to focus on the western homeland movement. While there was a great deal of interest in, and effort and financial resources expended on, the development of these outstations in both areas, in the long term, residence has tended to be spasmodic, with several of the sites now unoccupied and others used as weekenders or holiday centres. The larger centres such as Pipalyatjara and Wingelinna have taken on the characteristics of the older settlement-type communities with non-Anangu staff, stores, schools and art centres. The smaller outstations that have survived tend to be ones such as Kanpi, Nyapari and Watarru where stores and schools have been erected and staffed. 


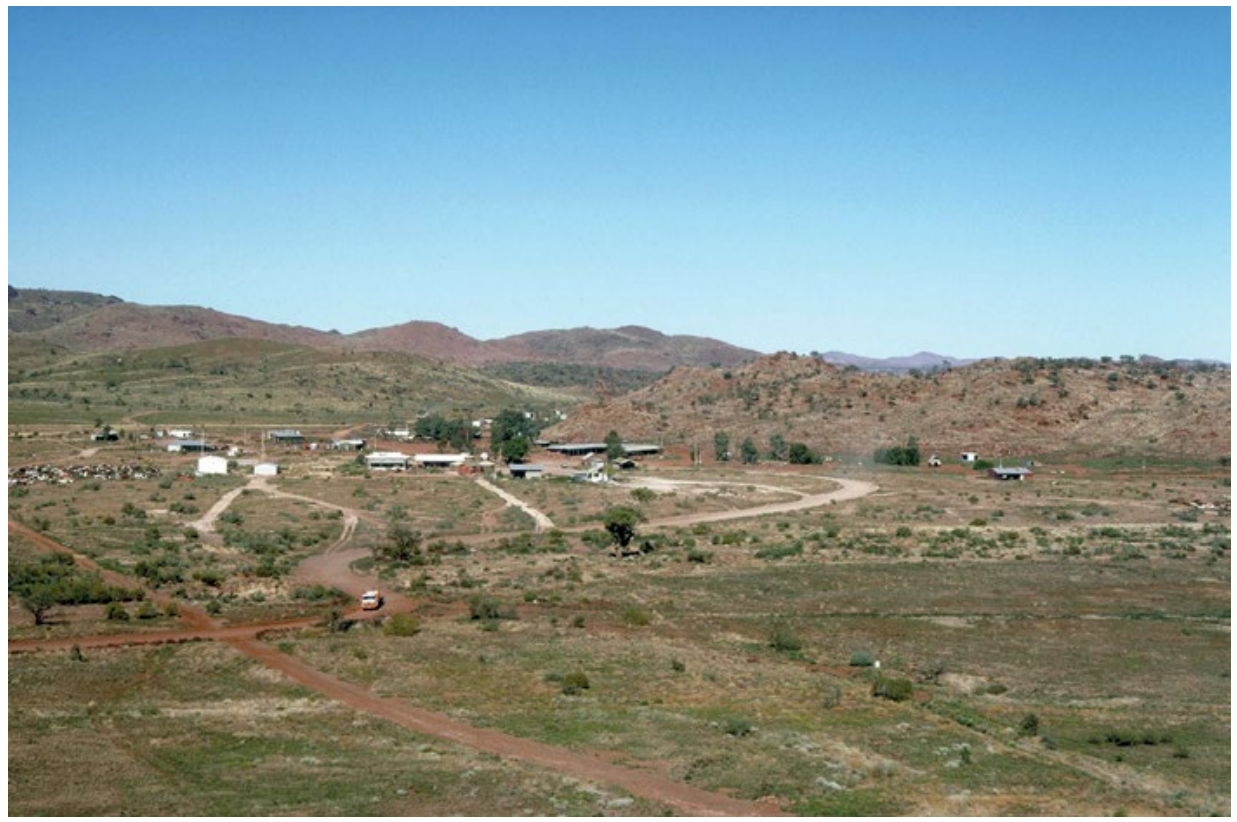

Figure 2.3 Pipalayatjara, 1989.

Source: Bill Edwards

Little attention was given in earlier reports to the role of non-Anangu people in supporting and facilitating this movement. Although some reports emphasised the motivation of 'leaving whites behind', several whites and other nonAnangu people were involved in the movement. Some outstation residents found that they needed the assistance of a white staff person to help them with finances, stores and other services. One man in 1976 expressed a motivation for having a white person on staff when he said to an adviser at Amata, 'If there is no white man, who will settle the arguments?' (B. Edwards 1988: 11). One researcher, Gerritsen (1982: 63), referred to 'white wayfarers'. The movement proved attractive to people involved in the alternative society movement in Western society in that era, sometimes referred to as 'hippies', whose values and practices contrasted with those of the more conservative people who had worked in the region previously. Whereas the latter had introduced work programs with sheep, cattle, gardens and building on the basis of 'no work, no food', Anangu were now told that they were owed a living without the discipline of work. Marijuana was introduced to the lands on the grounds that it was less dangerous than alcohol. However, young people began using both, with disastrous results. In recent years, I have interpreted in mental health institutions for people severely affected by marijuana. South American panpipes and yurt buildings were other innovations designed to promote peace and harmony. Another example of the influence of this influx of people associated with the alternative movement was an occasion when I visited Fregon in the late 
1970s and the community adviser asked me what he should do about the nikiti (naked) white fellows who were camped at, and running around, the Morrison Bore satellite outstation. Anangu whose parents had roamed the bush in a state of nakedness were sometimes bemused when calling at a house to be greeted by a naked white person.

\section{Conclusion}

Gerritsen referred to the outstation movement as 'a phenomenon of great complexity' (1982: 69). Some writers have tended to simplify the issues relating to the movement. On one hand, some with a romanticised vision overlooked the past movements of Anangu, stereotyped the role of the earlier established settlements and presented a model of the movement that is too simplistic. For example, Tregenza (1979), Waterford (1977) and others have overstated the extent to which people were forced or encouraged to move from their traditional sites in the earlier period, exaggerated the numbers of people who left the settlements to reside at homelands and largely ignored the tensions and social problems that led to people leaving the homelands, either to return to the settlements or to establish other outstations. The model that was often presented of an earlier mass movement largely forced by mission and government authorities from west to east and the later movement of large numbers from east to west does not take sufficient account of the complexity of the to-and-fro movement that continued throughout both periods.

On the other hand, Helen Hughes has given too little attention to the difficulties that Indigenous people, with their long attachment to land and language and their tradition of kinship obligations, face in adjusting to the dominant mainstream social, political and economic life in contemporary Australia. She assumed that they could have made this transition within a generation or two. Hughes overemphasised the influence of Nugget Coombs in the movement and underestimated the role of Aboriginal people themselves.

Having often camped with older people in these outstations, I have been aware of the comfort they have afforded Anangu who bore the brunt of white intrusion into their lands, made some adjustments to their way of life by working on cattle stations and other settlements but returned to their homelands in their later years. Their presence there contributed to the negotiations that led to the granting of title for these lands to Anangu Pitjantjatjara/Yankunytjatjara Incorporated under the Land Rights Act of 1981. It enabled the establishment of significant settled communities at Pipalyatjara and Wingelinna and smaller ones such as at Kanpi and Nyapari. Their occupancy of sites strengthened their case to be involved in negotiations in relation to possible mining and other 
developments. In places such as Watarru it has enabled them to participate in environmental programs such as the protection of threatened species. It also provided sites, resources and opportunities for people of shared descent who had been removed from the lands in earlier decades, or their descendants, to reclaim their Anangu heritage.

However, as instanced earlier, these communities have not been immune to the recent social problems in the region. My diary for the period contains several references to problems that occurred there when residents of Pipalyatjara and Wingelinna homelands brought alcohol to Amata when returning from liquor outlets on the Stuart Highway. This led to fights and families seeking refuge from men affected by alcohol.

I have sought to demonstrate that the homelands movement of the 1970s and 1980s was a more complex and multifaceted phenomenon than assumed in some writings of the period. Anangu responded to the challenges and opportunities of the era in a variety of ways as they sought relief from the tensions of their communities. However, three decades later, the problems of dependency, limited employment opportunities, substance abuse and occasional violence continue in both the older communities and the homeland outstations.

\section{References}

Brokensha, P. 1975. The Pitjantjatjara and Their Crafts. Sydney: Aboriginal Arts Board.

Brokensha, P. and McGuigan, C. 1977. Listen to the Dreaming. Australian Natural History 19(4).

Cane, S. and Stanley, O. 1985. Land Use and Resources in Desert Homelands. Darwin: North Australia Research Unit.

Coombs, H. C. 1974. Decentralization trends among Aboriginal communities. Search 5(4) (April).

Coombs, H. C., Dexter, B. G. and Hiatt, L. R. 1980. The outstation movement in Aboriginal Australia. Australian Institute of Aboriginal Studies [NS](14) (September).

Edwards, B. 1988. Pitjantjatjara decentralisation. Paper delivered at the Fifth International Conference on Hunting and Gathering Societies, Darwin, August-September. 
Edwards, B. 2009. An epic of the ordinary: The Uniting Church and Aboriginal missions. Uniting Church Studies 15(1) (June).

Edwards, B. 2012. Mission in the Musgraves: Ernabella Mission 1937-73, A Place of Relationships. Adelaide: Uniting Church Historical Society (SA).

Edwards, W. H. 2007. Moravian Aboriginal missions in Australia. PhD thesis. Flinders University of South Australia, Adelaide.

Gerritsen, R. 1982. Outstations, differing interpretations and policy implications. In P. Loveday (ed.), Service Delivery to Outstations. Darwin: North Australia Research Unit, pp. 57-69.

Heppell, M. and Wigley, J. J. 1977. Desert Homeland Centres: Their Physical Environment. Canberra: Aboriginal and Torres Strait Islander Housing Panel Inc.

Hughes, H. 2007. Lands of Shame: Aboriginal and Torres Strait Islander 'Homelands' in Transition. Sydney: Centre for Independent Studies.

Jack, R. L. 1922. Northmost Australia: Three Centuries of Exploration, Discovery and Adventure in and around the Cape York Peninsula, Queensland. Melbourne: George Robinson.

Kerin, R. 2011. Doctor Do-Good: Charles Duguid and Aboriginal Advancement, 1930s-1970s. Melbourne: Australian Scholarly Publishing.

Leske, E. (ed.) 1977. Hermannsburg: A Vision and A Mission. Adelaide: Lutheran Publishing House.

MacKenzie, G. 1981. Aurukun Diary: Forty Years with the Aborigines. Melbourne: The Aldersgate Press.

Martin, S. 2012. Outback town abandoned. The Advertiser, [Adelaide], 14 January.

Myers, F. R. 1986. Pintupi Country, Pintupi Self: Sentiment, Place, and Politics among Western Desert Aborigines. Canberra: Australian Institute of Aboriginal Studies.

Shepherdson, E. 1981. Half a Century in Arnhem Land. Adelaide: E. \& H. Shepherdson.

Toyne, P. and Vachon, D. 1984. Growing up the Country: The Pitjantjatjara Struggle for their Land. Melbourne: Penguin Books.

Tregenza, J. 1979. Pitjantjatjara: Back to the bush. Adelaide Preview (November). 
Wallace, N. 1977. Pitjantjatjara decentralistion in north-west South Australia: Spiritual and psycho-social motivation. In R. M. Berndt (ed.), Aborigines and Change: Australia in the '70s. Canberra: Australian Institute of Aboriginal Studies.

Waterford, J. 1977. Pitjantjatjara seek new health approach in homelands. The Canberra Times, 15 November. 
This text is taken from Experiments in self-determination: Histories of the outstation movement in Australia, edited by Nicolas Peterson and Fred Myers, published 2016 by ANU Press, The Australian National University, Canberra, Australia. 